\title{
Telling Friends from Foes in the Time of the Anthropocene*
}

Bruno Latour

\begin{abstract}
in Clive Hamilton, Christophe Bonneuil \& François Gemenne (editors) . The Anthropocene and the Global Environment Crisis - Rethinking Modernity in a New Epoch, London, Routledge p.145-155.
\end{abstract}

To Clive Hamilton

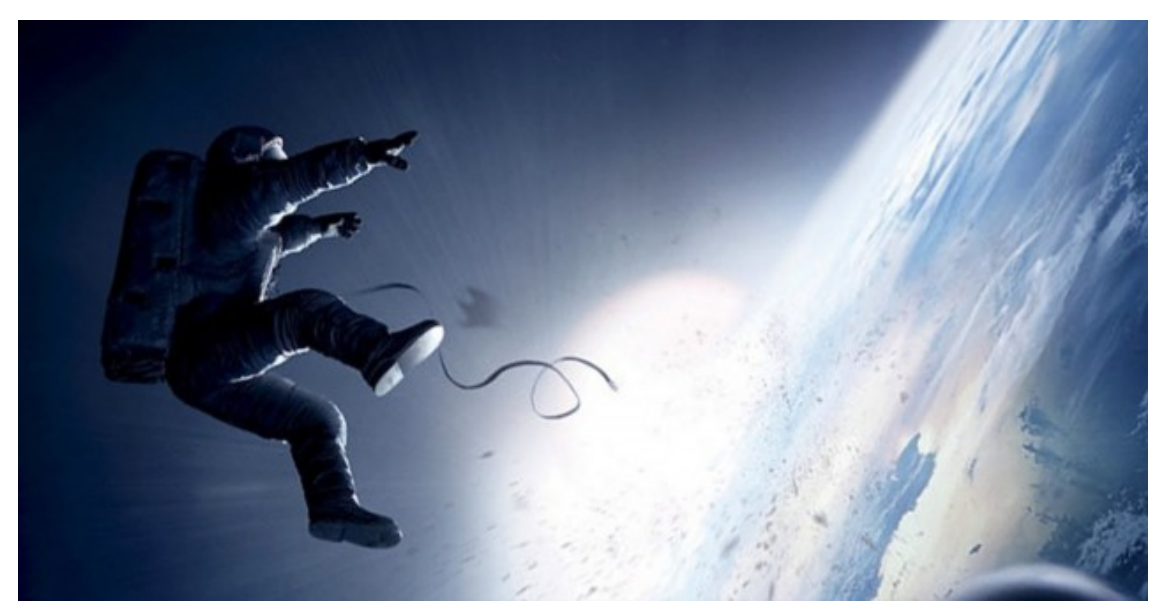

Those among you who have seen Gravity, the film by Alfonso Cuaron, will have noticed, I am sure, that once again a blockbuster's special effects offer a powerful symbol of a drastic change of mental state. For the human race there is no space anymore, at least no durable occupation of outer space. That is, there is no way to escape from the Earth. The main character, Dr Ryan Stone, confesses it at one point: "I hate space," she says while trying to run from one destroyed space station to the next. Even more forcefully than in Cameron's Avatar, the characters, and the spectators with them, realize that there is no longer any Frontier; no escape route except back on Earth. The

\footnotetext{
* This paper had been written initially for the symposium "Thinking the Anthropocene" Paris, 14th-15th November, 2013, EHESS-Centre Koyré- Sciences Po.
} 
direction is not forward, Plus ultra, but inward, Plus intra, back home. When Ryan, sole survivor of the space adventure, reaches the shore of the lake where she has finally landed and grabs a handful of dirt and mud, she has, literally, been metamorphosed from a human to an Earthbound, while the old-fashioned American hero played rather clownishly by her teammate George Clooney has vanished forever in outer space, debris among the debris of the European and Chinese space stations. Much as in von Trier's Melancholia, in Gravity we witness the step-by-step destruction of the old Galilean idea of the Earth as one body among other spatial bodies. We are forced to turn our gaze back to sub-lunar Gaia, so actively modified by human action that it has entered a new period, geologists-turnedphilosophers propose to call that of the Anthropocene.

In spite of its pitfalls (Bonneuil and Fressoz 2013), the concept of Anthropocene offers a powerful way, if used wisely, to avoid the danger of naturalization while ensuring that the former domain of the social, or that of the "human", is reconfigured as being the land of the Earthlings or of the Earthbound. Like Aesop's tongue, it might deliver the worst - or worse still, much of the same; that is, the back and forth movement between, on the one hand, the "social construction of nature" and, on the other, the reductionist view of humans made of carbon and water, geological forces among other geological forces, or rather mud and dust above mud and dust. But it might also direct our attention toward the end of what Whitehead (Whitehead 1920) called "the bifurcation of nature," or the final rejection of the separation between Nature and Human that has paralyzed science and politics since the dawn of modernism.

The jury is still out on the staying-power of this concept of the Anthropocene (its half-life might be much shorter than I think). Right now, however, it is the best alternative we have to usher us out of the notion of modernization. Like the concept of Gaia, the risk of using such an unstable notion is worth taking. Especially if we wish, as we do in this book, to probe the philosophy and theology of such a novel concept. The dreams that could be nurtured at the time of the Holocene cannot last in the time of the Anthropocene. We might say of those old dreams of space travel not, "Oh, that is sooo $20^{\text {th }}$ Century," but rather "Oh, that is sooo Holocene!" In this sense, the use of this hybrid term made up of geology, philosophy, theology and social science is a wake up call. What I want to do is to probe here in what sort of time and 
in what sort of space we do find ourselves when we accept the idea of living in the Anthropocene.

But, just as it was for Dr Ryan Stone, the problem is that it is difficult for those who have been moderns (that is, for those who have never been modern) to find their ways back to Earth! Just like Dr Ryan, they miss and they lack gravity... Especially because most of our ways to map where we are, where we are heading and what we should do, have been defined by a division of labor between science and politics - what I have called the unwritten Constitution (Latour 2014). This Constitution is totally illadapted to handle the conflicts we have to navigate. In fact it is so ill-adapted that even the notion of conflict, or rather to call a cat a cat, the state of war that is the defining trait of the Anthropocene, is constantly downplayed or euphemized. In such an epoch, both science and politics take a totally different shape.

$\mathbb{S}$

The spurious debate about climate science is a good indicator of that new shape. On the one hand, there is no debate whatsoever, and no question of natural history has been better settled than the anthropic origin of climate change. With the last IPCC report, all nations, it appears, are bracing themselves for a world $4^{\circ} \mathrm{C}$ warmer (and that might be the optimistic scenario!). And yet, it is useless to keep saying that "there is no discussion." No matter how spurious a controversy, it remains that for a large part of the population, there is a controversy, the effect of which we may witness everyday through the total inertia - I might use the word "quietism" only to reassure myself - of governments as well as of civil societies that are supposed to exert a pressure on their elected proxies.

You will never find a bookshop in France that would put a book by Claude Lanzmann on the Shoah side-by-side on a table with a book by an arch negationnist like Faurisson. A few days ago, however, my friend Clive Hamilton was horrified to see his book, Requiem for a Species (Hamilton 2013), together with one of the newest pamphlets (Gervais 2013) by a climate denier "L'innocence du carbone" (amazing title, I will come back to that). And the worst is that Clive would have appeared unfair and dogmatic if he had taken the manager to task for keeping such an absurd and scandalous balance. If he had protested, no doubt the manager would have answered that this is a "rational debate" and that "both sides" have to be heard. There is a law (in France) against Faurisson; not against climate negationnism. 
And that is one of the problems that paralyze politics in the Anthropocene. This is not a rational debate. Or rather, it is a debate for which the climatologists of the IPCC who would have been considered rational in another climate are being rendered powerless. They are portrayed as irrational by those who use the power of reason and appeal to the freedom of scientific inquiry to pollute not only the atmosphere but also the public sphere, to use James Hoggan's expression (Hoggan 2009). Why? Because both sides - and this is what produces the idea that there are two sides - use the same scienceversus-politics repertoire.

This repertoire is made of two parts. First, both sides imply that Science is about distant, dispassionate facts of nature while politics is about ideology, passions and interests whose intrusion into Science cannot do anything but distort the plain facts. Second, both sides agree that policy should follow scientific expertise and that we cannot make decisions based on uncertain science. Part one: science is about incontrovertible and indisputable facts; part two: policy follows science. The difficulty is that this repertoire (disproved by fifty years of historical case studies) is shared by most of the public as well. It means that if any lobbyist paid by the mining or oil industry, or any physicist with his own pet version of what the laws of nature tell him, manages to introduce the smallest grain of doubt into the expertise, the whole policy train stops. Since this is what all politicians, as well as every onlooker believe, and since it is also the way TV shows organize debates as if they were judges in a courtroom, it is incredibly easy to make two sides emerge even when there is only one.

To give credit where credit is due, this should be called the Luntz strategy to honor Frank Luntz's infamous memo to the Republican party: "Should the public come to believe that the scientific issues are settled, their views about global warming will change accordingly. Therefore, you need to continue to make the lack of scientific certainty a primary issue." His success speaks volumes about the mass of money spent to foster climate deniers but it also speaks to the fragility of the immunological system of those who use the science-versus-politics repertoire. It appears that the slightest virus is enough to make them doubt and stop policy in its tracks. Because of this weird though common-sensical - vision of science versus politics, there is no way to immunize the public against such an infectious form of "skepticism" - a grand adjective that has been most maliciously appropriated. 
Of course, it would be welcome if we could imagine that at some point, because of the many public debates about the issue, the two sides would become one. Case settled, let's now move on to the policy. The apparently innocuous term "skepticism", used so intently by deniers, might seem to lead in such a direction. Let us have a "fair and balanced" debate, as they say on Fox News. But there is not the slightest chance that this closure will ever occur, since the deniers' success is not to win any argument, but simply to make sure that the rest of the public is convinced that there is an argument. How could the poor helpless climatologists ever win in such a kangaroo court where the point is not to reach a verdict (the verdict has been reached in the IPCC report already anyway). The new discipline of "agnotology", to use James Proctor's expression (Proctor and Schiebinger 2009), is the willful production of ignorance that has functioned marvelously for cigarettes as well as for asbestos, and with more resistance, for extermination camps. It will work much better, and for much longer, for climate science, and for one additional reason: it is about the daily life of billions of people. The chance to ever reach closure is nil. And yet waiting for closure before drafting policy is not an option either.

This is the Achilles' heel of Mr Luntz's strategy. Not in trying to achieve closure by reasonable debate - the dice are loaded as long as there appear to be two sides - but in opposing the science-versus-politics repertoire with a much more reasonable, and on the whole much more rational, alternative repertoire. There are two sides, it is true, but not between climatologists and climate-deniers. There are two sides between those who stick to a traditional science-versus-politics version and those who have understood that this older political epistemology (to call it by its real name (Latour 2004)) is what renders both politics and science weak when the issues at stake are too large for too many interested people directly affected by their decisions. This is where there is a real distinction to be made between a Holocene and an Anthropocene settlement. What might have been good for Humans (and I doubt it ever was the case) has lost any sense for the Earthbound.

The great limit of the old settlement was to make impossible any connection of science with politics and not versus politics. For this of course one has to abandon the idea that the only thing politics may do is to distort facts! Although this version of politics is as old as Socrates fighting against Calicles, it flies in the face of everything we expect from politics: building a 
collective polity on a precisely defined soil or land - now, more precisely and more extensively, a polity that has an Earth under its feet, so to speak. Politics has gravity when it has a territory to defend.

But one should also abandon the idea that science is about incontrovertible and indisputable facts. Science, always with a small s, is about producing, through the institutions of many disciplines and the monitoring of many instruments, robust access to a great number of entities with which the polity has to be built. In this view both science and politics are mundane, rather humble, frail and pedestrian activities, open to doubt, revision, and prone to mistakes as soon as their delicate operations are not constantly supported.

As I have shown in Politics of Nature (Latour 2004), the only thing they cannot afford to do is to work separately. Their skills are obviously and fortunately totally distinct but they have to exercise themselves on the same new entities whose novelty they have to learn in common how to domesticate. Without the instruments of science, the body politic will never know how many strange entities it has to take into account. And without politics, the same body politic will never know how to array, grade, and rank those bewildering number of agencies with which it has to progressively compose a common world - which is the definition I proposed for politics-withscience. The great paradox of the Moderns is to have granted, to the absolute distinction of Science and Politics, the task of maintaining facts and values as clearly separated as possible. Unfortunately, the common sense opposition between facts and values is everything but common sense since the notion of "facts" covers what is still uncertain just as well as what is undisputable (what triggers perplexity and what has been well instituted) while the notion of "values" is supposed to designate who should allocate the dispute as well as the order in which all the objects of values should be ordered (what requires a consultation as well as what demands to be put into a hierarchy). To be sure there is a difference, but it runs along an exactly orthogonal direction to the calamitous one between facts and values: it should bring science and politics (plus many other trades) to bear on the two essential tasks: defining how many entities have to be taken into account (namely perplexity and consultation); and how they can stand together in a livable form (that is hierarchy and institution). 
There is perhaps one comforting thing to say about the Anthropocene. It has demonstrated that the ancient settlement was rendered useless as soon as issues became too touchy or concerned too many people. The old settlement worked - if it ever did - only in the rarefied air of outer space, for distant problems that interested only a few people and had indirect, remote consequences. This ancient settlement has certainly not worked for what concerns us in the present - or worse, concerned us in the past - where the background and foreground have merged. This is exactly what the word Anthropocene underlines so well. When action modifies the very framework in which history is supposed to unfold, the idea of distant, disinterested facts becomes less relevant than that of highly disputed matters of concern.

$\mathbb{S}$

To shift from a science-versus-politics to a science-with-politics is of course not without danger. At first glance, climate deniers will have a field day clamoring that their adversaries have finally confessed what they, the deniers, have always said: climate science is politics. To which the only reasonable answer is: "Yes, of course, where have you been? And what are you doing yourself?" After a minute of hesitation because of the loss of the old settlement - it is not easy to lose confidence in the Maginot line of factversus-value! - those who fight against the deniers should quickly grasp how to redraw the lines of conflict. Not between two sides of an epistemological debate (on one side the climate science and, on the other, the climate skeptics), but between two sides - and they will be soon more than two - with a completely different view of what you may expect from science as well as from politics. There is no conflict between science and politics. But there is a conflict between two radically opposite political epistemologies, each with its own definition of what science and politics are, and how they could collaborate.

Of course, there exist plenty of reasons for imitating what feminists call "strategic essentialism" and to employ, whenever necessary, a form of "strategic positivism" as if we could confide to a settled science of the climate the task of serving as an incontrovertible premise for policy. But even if this strategy could succeed (and the weak response to the last IPCC report indicates that it has failed this just the same as all previous attempts to "convince" the public), it would not solve the question because it would remain a pedagogical gain - not a political one. More people would know for sure, which is always good, but they will not be moved an inch out of the 
situation of just knowing. We are not dealing here with indisputable "matters of fact," but with "matters of concern" to be disputed. It is a question of knowing "uncomfortable facts" about pressing issues that concern the very soil on which every body resides.

It should have become clear that expressions like "the innocence of carbon" as well as "uncomfortable facts" straddle the distinction between facts and values. How could it be otherwise since we are talking here about conflicts that pit against one another different definitions of the land to which the various polities are attached? How could any one, I beg you, defends one's territory quietly and dispassionately when it is under attack? The only result of the older settlement of fact-versus-politics is that, in such a conflict, one side fights with all the forces at its power while the other side, the rational and reasonable climatologists, must fight with their hands tied behind their backs by the injunction that they, and they alone, should protect the sanctity of Science (capital S) against any encroachment of ideology and interest.

In the old days, such an alternative political epistemology could have smacked of "relativism". But today it is much clearer that when opponents reach for their guns and mention the "science wars" it is much fairer, and, once again, more rational to say: "Not a science war, but for sure, a war of the worlds". Or rather, a war for the occupation and definition and composition of what the world, at least this sublunary planet, Gaia, is like. How could we agree on this composition since, depending on the answer, each of us has to move literally to another place? How could we settle the issue when, depending on the response given, we ally with other people and break sides with others? Paradoxically, capitalists seem to know what it is to grab, to possess and to defend a land more than their space-less adversaries who have to defend Science and its View-from-Nowhere for inhabitants of no place. At least they know to which soil they pertain better than those who keep defending themselves by an appeal to the extraterritorial authority of Science. Remember the Bushist's war cry: "Americans are from Mars, Europeans are from Venus"? Well, it seems that those traditionally-defined nations are neither from Mars nor from Venus, but some are from an Earth which has a specific shape and some are from another Earth, or, maybe, from a land of no land called "utopia", the utopia that the Moderns have imagined as their only future (Danowski and de Castro 2014). A future that now looks just like the destroyed space stations from which Ryan Stone tries to escape in Gravity. 
$\mathbb{S}$

In addition to "strategic positivism", there is fortunately another resource we could use to clarify the conflicts we must confront living in the Anthropocene. It is not true that the general public, the one that is so easily contaminated by Luntz's viral infection (a dangerous metaphor, I agree), is endowed with the sole repertoire of science-versus-politics. Most of them are ordinary people who act most of the time in a universe made of uncertain facts that concern them a lot. Before investing in a company or having children or buying travel insurance, they don't wait for completely incontrovertible evidences and only then jump into action. If there is one thing everybody can understand, it is that when their life is put into question, when the territory on which they live is threatened, when they are attacked by other people who want their place, their land, their soil, their cherished plot of earth, what used to be called their "mother land", they certainly don't wait for experts to agree. They need to quickly identify those who can help and those - is there another word for it? - who risk betraying them. Making decisions amongst contradictory evidence about pressing issues, this attitude is common to scientists, politicians and ordinary members of the public. Such a common sense attitude takes full force when their territory is under threat. What could be called mobilization is an uneasy, worrisome, dangerous feeling, a source of ill-defined consequences, but one thing is sure: in case of war, the attitude is not of complacency, appeasement and delegation to the experts.

It is bizarre that militants as well as "concerned scientists" (a venerable label from the former fights around the virtual nuclear holocaust) could simultaneously complain about the lack of mobilization of the public and of their elected representatives, while trying to euphemize the conflict by shying away from the word "war". Their adversaries have no such qualms. For them, it is a forceful land grab: the land is theirs and they hold to it fast. That they try to hide behind the mantle of Science is a simple ploy (they are actually the ones playing the game of strategic positivism! And they do it to its limit). We should not be surprised by this appeal to Science. That "Gott Mitt Uns" has always been embroidered on the banners of earlier war parties, does not mean that God ever sided with any of the warring factions. Even though it might be perilous to speak of war -when there is a state of peace- it is even more dangerous to deny that there is a war when you are under attack. Appeasers would end up being the deniers - not by denying 
climate science, this time - but by denying that there is a war for the definition and control of the world we collectively inhabit.

There is indeed a war for the definition and control of the Earth: a war that pits - to be a little dramatic - Humans living in the Holocene against Earthbound living in the Anthropocene. What I take to be the clarifying effect of stating this, is that it makes possible for the various camps to fly "under their own colors" (to use Walter Lippmann's expression (Lippmann 1925), and not under the flag of "Gott" or rather "Natur Mitt Uns". When you meet climatosceptics who have the nerve to call the IPCC "a lobby", it would be much more powerful to answer: "Of course it is a lobby, now let us see how many are you, where does your money come from. And, since we are at it, since you are accusing us of being biased by 'an ideology', let's put everything on the table: in what world do you live, where, with what resources, for how long, what future do you envision for your kids, what sort of education do you wish to give them, in which landscape do you wish them to live." And, step-by-step, the whole set of differentiated power relations that are so blatantly missing from the common notion of the Anthropocene would be brought back. Such a counter-attack is exactly the opposite of retreating behind the Maginot line of a Science unpolluted by politics.

Of course, this geo-graphy or, rather, this Gaia-graphy requires a description of the front lines. For such a delineation, we need all the resources of all the disciplines, be they social or natural. "Please, delineate what you are defending, what do you think the land is worth, with what other organisms, what sort of soil, what sort of landscape, what sort of industry, what sort of commerce you wish to survive with." For instance, let us pit "Innocent carbon" against "Carbon democracy" (the title of Timothy Mitchell's crucial book (Mitchell 2011) since both straddle the fact/value distinction. In both accounts, carbon does not play the same role, does not receive the same qualifications, does not have the same properties. Fine. This does not prove any distortion of scientific facts. It means that there are many ways for carbon to be composed into a common word. If the same atoms can generate materials as different as graphite and diamond, should we be surprised that the same carbon in the hands of a climate denier has different arrangement and virtues, that is, different agencies, than in those of an historian of the Middle East? "Innocence" and "guilt" are properties of atoms that, very exactly, very literally, depend on their composition. 
All those connections, what John Tresch calls those "cosmograms" (Tresch 2001), can be made explicit only if we don't break them according to the science-versus-politics divide. Of course, such geopolitics, or rather such Gaiapolitics, does not correspond to the old coloured maps over which so many wars have been waged (Elden 2014). The borderlines are difficult to detect, but it does not mean that it is not about territories, that those new maps don't have to be drawn and that it is not about conflicts. How could we introduce the concept of the Anthropocene and not draw the consequences in terms of politics of the Earth? Mines, rivers, pollution, oceans, fish, fowl, grass, insects, clouds, rain and floods, they are all there.

What is a territory if not that without which you would not be able to live? Well, list all those beings, those agencies you say you can do without. We will do ours. Then we will draw the territories that are under attack, those that are worth defending, those that could be abandoned. Once this is done, we might compare our chances of losing or of winning. Since appeals to Nature known by Science and its Laws - the older State of Nature - does not bring peace even in the case of such a hardened fact as that of the anthropic origin of climate change, then we should accept living in a declared state of war. And anyway, our opponents are more attuned to what is at stake, better versed in what the words "possession" and "defense of one's possessions" mean. They, our adversaries, mobilized long ago.

$$
\mathbb{S}
$$

The real advantage of making the state of war explicit instead of undeclared is that it might be the only way to begin to envisage peace. Not a pedagogical peace obtained through the older science-versus-politics repertoire; as if we could begin to discuss policy now that we have all learned the natural sciences so that we necessarily agree with one another about what makes up the world. But instead a political peace. One negotiated by the camps who, having exhausted all other options, and knowing that neither the "God" nor the "Nature" embroidered on their banners are really behind them, attempt a settlement as if there was no arbiter above their heads. The main difference between the two forms of peace is that the pedagogical one comes before any war. Then war is simply the irrational mistake of those who have not understood the laws of nature or of economics; peace will be brought back once everyone has learned the truth about what things are and always have been. Pedagogical peace is akin to police intervention or to what is today called "governance". By contrast political peace comes after the war has exhausted the warring parties, who end up composing what is exactly 
named, a modus vivendi, that is, an entangled set of makeshift arrangements to survive.

It is because the political peace is not dictated by what is already there but by what should be progressively realized that there is no way to delay it any more. Delay is part of the Modernist dream. Actually, it is their definition of the future. A future made of nothing but a flight from the past and "eyes wide shut" to what is coming. This is where the concept of the Anthropocene meets not only a philosophy of science - the politics-with-science repertoire instead of politics-versus-science, not only a definition of the ground on which polities are built — but also a "Gaia-politics" of highly contested grounds. And, so important theologically: the Anthropocene meets another time, as different from the modernist one as its spatial rooting. This inclusion of theology into ecology is formulated in many ways, from the more secular version offered by Jean-Pierre Dupuy — "enlightened catastrophism" (Dupuy 2003) - to the more spiritual version proposed by Michael Northcott (Northcott 2013) - what I have called a "carbon theology"!

What they have in common is that, in the same way as they propose a different spatial grounding for each warring camp, they offer another temporal rhythm for action. Action cannot be delayed because time does not flow from the present to the future - as if we had to choose between scenarios, hoping for the best - but as if time flowed from what is coming ("l'avenir" as we say in French to differentiate from "le futur") to the present. Which is another way to consider the times in which we should live as "apocalyptic". Not in the sense of the catastrophic (although it might be that also), but in the sense of the revelation of things that are coming toward us. This odd situation of living "at the end of time" in a different type of hope, the hope that has been made one of the three theological virtues and that the French, once again richer than English, calls "espérance" to make sure it is not confused with "espoir". Clive Hamilton has wisely advised us to jettison this "espoir", this hope, because, as long as we rely on hope, we still expect to escape from the consequences of our action. It is only once we have radically changed our relation to time - what is called living in "apocalyptic times" that we might be spurred into action without delay (Anders 2007). "The times are fulfilled". 
Historians of ecology are right to say that there is probably nothing completely new in the concept of the Anthropocene since conflicts about territories and their resources are as old as the human race and since warnings about the consequences those "land grabs" have on the environment are as old as the Industrial Revolution (Bonneuil and Jouvancourt 2014). What I take to be really new in this Anthropocene label (apart from the unusual collaboration between geology, history - or rather geostory - politics and philosophy) is that it modifies simultaneously the spatial and temporal frames in which action is being situated; and, moreover, that this frame has modified the two main pillars on which the metaphysics of Science has been established since the "bifurcation of nature", to use Whitehead's famous description.

How odd it has been for the Moderns to imagine that their materiality could be made of atomic points without spatial extension and of instants without duration. It is this most idealistic definition of matter that is showing now its utopian and toxic character. It is such an odd conception that has been so constantly at odds with the experience of space and of time. It has rejected every impulse that insisted on being "from a place and having duration" as being nothing but mere subjectivity, poetry, theology or philosophy. To the point that the Modernist dream may be defined as a constant fight to replace the "subjective" space and time by a really rational view of a space belonging to no space and a time made of timeless instants. It is fair to say that civilization has been a long fight, mainly lost, of resisting, for good and bad reasons, such a definition of the modernizing frontier. Well, now, through a completely unexpected inversion of the respective positions of every field of inquiry, the many disciplines of natural history are calling for a return to the spatial conditions of the Earth and for an urgent sense that "times are fulfilled". Gaia is not nature; and it is not a polity either. Scientists are fighting many other battles. They discover totally different friends and foes. And so do we all. There is no modernizing frontier any more. Instead there are so many new lines of conflicts that a totally different Gaia-politics is now redrawing all the maps (Stengers 2009 and this volume). So by remixing all the ingredients of what used to be distinct domains of subjectivity and objectivity, the very notion of the Anthropocene is indeed an enormous source of confusion - but a welcome source. Like that of Dr Ryan Stone, our collective return to Earth is a rather traumatic one. But at last we know where we are and what we should fight for. Ah! But should we not have 
known that all along? "Memento, homo, quia pulvis es, et in púlverem revertéris;"

"Remember, man, that thou art dust, and unto dust thou shalt return." 


\section{References}

Anders G 2007 Le temps de la fin Editions de l'Herne, Paris

Bonneuil C and Fressoz J-B 2013 L'évènement anthropocène: La Terre, l'histoire et nous Le Seuil, Paris

Bonneuil C and Jouvancourt P D 2014 En finir avec l'épopée. Récit, géopouvoir et sujets de l'anthropocène in Hache E ed De l'univers clos au monde infini (textes réunis et présentés) Editions Dehors, Paris

Danowski D and Castro E V D 2014 L'arrêt de monde in Hache E ed Del'univers clos au monde infini (textes réunis et présentés) Editions Dehors, Paris

Dupuy J P 2003 Pour un catastrophisme éclairé: Quand l'impossible est certain Le Seuil, Paris

Elden S 2014 The Birth of Territory University of Chicago Press, Chicago

Gervais F 2013 L'innocence du carbone Albin-Michel, Paris

Hamilton C 2013 Requiem pour l'espèce humaine (traduit par Jacques Treiner et Françoise Gicquet) Presses de Sciences Po, Paris

Hoggan J 2009 Climate Cover-Up:The Crusade to Deny Global Warming Greystone Books, Vancouver

Latour B 2004 Politics of Nature: How to Bring the Sciences into Democracy (translated by Catherine Porter) Harvard University Press, Cambridge, Mass

Latour B 2014 War and Peace in an Age of Ecological Conflicts Revue Juridique de l'Environnement 151-63

Lippmann W 1925 [1993] The Phantom Public Transactions Publishers, New

Brunswick

Mitchell T 2011 Carbon Democracy: Political Power in the Age of Oil Verso, New York Northcott M S 2013 A Political Theology of Climate Change Eerdmans Publishing, Grand Rapids, Michigan

Proctor R and Schiebinger L 2008 Agnotology: The Making and Unmaking of Ignorance Stanford University Press, Stanford

Stengers I $2009 \mathrm{Au}$ temps des catastrophes. Résister à la barbarie qui vient Les

Empêcheurs, Paris

Tresch J 2012 The Romantic Machine: Utopian Science and Technology after Napoleon University of Chicago Press, Chicago

Whitehead A N 1920 Concept of Nature, Cambridge University Press, Cambridge

\footnotetext{
${ }^{\text {i } I n ~ a ~} 2002$ memo to President George W. Bush titled "The Environment: A Cleaner, Safer, Healthier America", obtained by the Environmental Working Group (Wikipedia page on Luntz, accessed 4 July 2014).
} 